\title{
Loss of Macronutrients (N, P, K) in the Hydrographic Basin of the River Ivaí, an Affluent of the River Paraná
}

\author{
Deborah Maria Corrêa Guiraud ${ }^{1}$, Ervim Lenzi ${ }^{2 *}$, Eduardo Bernardi Luchese ${ }^{2}$ and Luzia \\ Otília Bortotti Fávero ${ }^{2}$ \\ ${ }^{1}$ Departamento de Química; Universidade Federal do Paraná - UFPR; Curitiba - PR - Brazil ${ }^{2}$ Departamento de \\ Química; Universidade Estadual de Maringá - UEM; Av. Colombo, 5970; 87020-900; Maringá - PR - Brazil
}

\begin{abstract}
Influence of some environmental variables in the loss of macronutrients $N, P, K$, from the hydrographic basin of the River Ivaí were analysed. Water samples of the river were monthly collected for five consecutive days during a year. In terms of total intervals of average monthly values and total average values experiment results, in $\mathrm{mg}^{1}$, were: $N$ (0.32-3.22 and 1.65); $K$ (0.73-2.69 and 1.38); $P$ (not detected-0.39 and 0.076); $C O D$ (0.21-36.0 and 12.8); $O_{2(d i s)}$ (1.89-8.40 and 5.43); and temperature $\left({ }^{\circ} \mathrm{C}\right)$ (16.0-30.8 and 24.6); $p H$ (5.18-8.50 and 7.15). Statistical analysis of data showed that quantity of macronutrient $(N, K, P)$ carried off from the hydrographic basin of the River Ivai were directly correlated to fluviometric levels (caused by rainfall and floodings) at $5 \%$ level of significance. Carried off quantities, in $t a^{-1}$, were $N=25,136.0 ; K=21,010.0$ and $P=1,161.2$.
\end{abstract}

Key words: Erosion, macronutrients, hydrographic basin, environment

\section{INTRODUCTION}

The $16^{\text {th }}$ World Congress of Soil Science emphasized the relationships between human societies and the soil cover. Among these relationships, soil and water conservation are well identified challenges, which have given rise to more than 50 years of research on soil erosion around the world. One of the main concerns is to allow sustainable soil cultivation (Auzet et al., 2001).

Intense directionless occupation of soils in agriculture leads to imbalanced ecology. One of the greatest negative environmental impacts produced by such occupation is the process of soil erosion (Cerdan et al. 2002; Van Muysen and Govers, 2002; Usón and Ramos, 2001; Zhou and Zhu, 2001) and the consequent lixiviation of nutrients to the rivers (Drechsel et al, 2001; Sequi et al., 1991; Bittencourt, 1982), causing eutrophication of the water body (Withers and Lord, 2002; Jaworski et al., 1992; Rosensteel and Strom, 1991; Esteves, 1988). It may also cause contamination and pollution of the environment (Manahan, 1994; Rose et al., 1991; Rossi et al., 1991) and cause a potential health hazard (Withers and Lord, 2002).

The capacity of mankind to produce food and live in an unpolluted environment depends on their ability to control the speed at which soil erosion is taking place (Poesen, 1996). Key factors upon which models of soil erosion are based for global changes are climate and atmospheric $\mathrm{CO}_{2}$ concentration that affects the hydrologic cycle and erosion caused by water and wind (Williams et al., 1996). Erosion is thus the main soil deterioration

\footnotetext{
* Author for correspondence
} 
factor caused by humans. It is the principal threat to sustainable management of soil (Ingram et al., 1996). Sustainable agriculture and its controversies have been headlined in the last few years (Hoag and Skold, 1996; Lee, 1996; Thompson and Pretty, 1996). Blair and McSherry (1996) state that the philosophical nucleus of sustainable agriculture is an ethical injunction in which the management of landscape intertransformation and earth resources, soil, energy, water, air, biota diversity, etc, are taken into account.

Within this range of philosophy, techniques have been developed in the last few years throughout the world for the correct use of soil. To minimization the effects of erosion and soil degradation were proposed several techniques for soil manipulation, such as, contour hedging, contours with permanent grass, direct plantation, crop rotation, use of geosynthetic mulching mat and others (Ahn et al. 2002; Chisci, et al. 2001; Malik et al. 2000; Dewald, 1996; Alegre and Rao, 1996; Dalton et al., 1996; Midimore et al., 1996; Perret et al., 1996; Wyland et al., 1996; Kloke, 1996).

\section{General Aspects of the River Ivaí Basin}

The River Ivaí is an affluent of the River Paraná, upstream Itaipu dam, and has a hydrographic basin of $36,000 \mathrm{~km}^{2}$ within the state of Paraná (Brazil) containing excellent lands for agriculture and pasture. Some of its micro-basins have model soil management (Busscher et al., 1996). There are almost no forests in the basin and climate is temperate. Average yearly rainfall is $1,500 \mathrm{~mm}$ with January, February and March as the most rainy months.

The following data on the River Ivaí basin were supplied by DNAEE-ITAIPU:

- Due to abundant rainfall and good soil conditions the basin surface drainage is considerable when specific discharge ranging from 17 to $20 \mathrm{~L} \mathrm{~s}^{-1} \mathrm{~km}^{-2}$ along the basin is taken into consideration.

- Long range average discharge of the River Ivaí at the beginning of the lower stretch in Porto Paraíso do Norte is $483 \mathrm{~m}^{3} \mathrm{~s}^{-1}$ for 1954-1981. Due to rainfall distribution throughout the year a clear seasonal regularity of average monthly discharges has not been observed.

- Floodings occur with great intensity and throughout the year. The highest value reaching
$6,072 \mathrm{~m}^{3} \mathrm{~s}^{-1}$ was observed in Porto Paraíso do Norte.

The aim of this work was to evaluate of loss of macronutrient $\mathrm{N}, \mathrm{P}$ and $\mathrm{K}$ occurring naturally by erosion lixiviation and percolation of the River Ivaí basin and identification of the possible dependence with some environmental responsible variables.

\section{MATERIALS AND METHODS}

\section{Site, periodicity and sample form}

According to data of The National Department of Water and Electricity (DNAEE), 30 fluviosedimentometric stations are present along the River Ivaí. The station at Paraíso do Norte, Figure 1, was chosen owing to its $90-\mathrm{km}$ distance from Maringá, Paraná, making daily collections feasible during five days and repeated monthly throughout the year (WMO, 1988). From the composed water samples, $1.5 \mathrm{~L}$ aliquots were separated for each element (N, P, K and COD Chemical Oxygen Demand). Precautions were taken with regard to representative character of the composite samples (Keith, 1996), cleaning of material and contamination avoidance (WMO, 1988; Moody and Linstron, 1977); type of material used in collection, storage and sample conservation (Bartram and Balance, 1996; Souza and Derísio, 1977; Wagner, 1976; Mart, 1979).

\section{Variables measured during collection}

Temperature, $\mathrm{pH}$, concentration of DO (Dissolved Oxygen) and river level on the limnimetric scale of the station were measured and or registered during collection.

\section{Analysis of total Nitrogen (N)}

Nitrogen was characterized as total $\mathrm{N}$ by Kjeldahl method (Horwitz, 1980; CETESB, 1978a).

\section{Analysis of total Phosphorus (P)}

Samples were initially digested with sulphuric acid - ammonium persulphate. Measurement of phosphorus $\left(\mathrm{PO}_{4}{ }^{3-}\right)$ concentration was made by spectrophotometric method UV-VIS of ascorbic acid, ammonium molybdate and potassium antimoniltartarate at $\lambda=880 \mathrm{~nm}$ using Spectrophotometer (GBC UV-VIS 918), (Horwitz 1980; CETESB, 1978b). 
Analysis of total Potassium (K)

Samples were pre-concentrated and digested with concentrated $\mathrm{HNO}_{3}$ (Horwitz, 1980). Potassium concentration was determined by atomic absorption spectrometry, by Spectrometer (AA CG 7000 ABC, Scientific Instruments Ltd). (Welz and Sperling, 1999; CETESB, 1978c).

\section{COD}

Samples were digested with the excess of potassium dichromate in a strong acid environment $\left(\mathrm{H}_{2} \mathrm{SO}_{4}\right)$ in ebullition and with reflux system for two hours. After cooling, excess of dichromate was titrated with ferrous sulphate with ferroin as indicator (Braile and Cavalcanti, 1993).

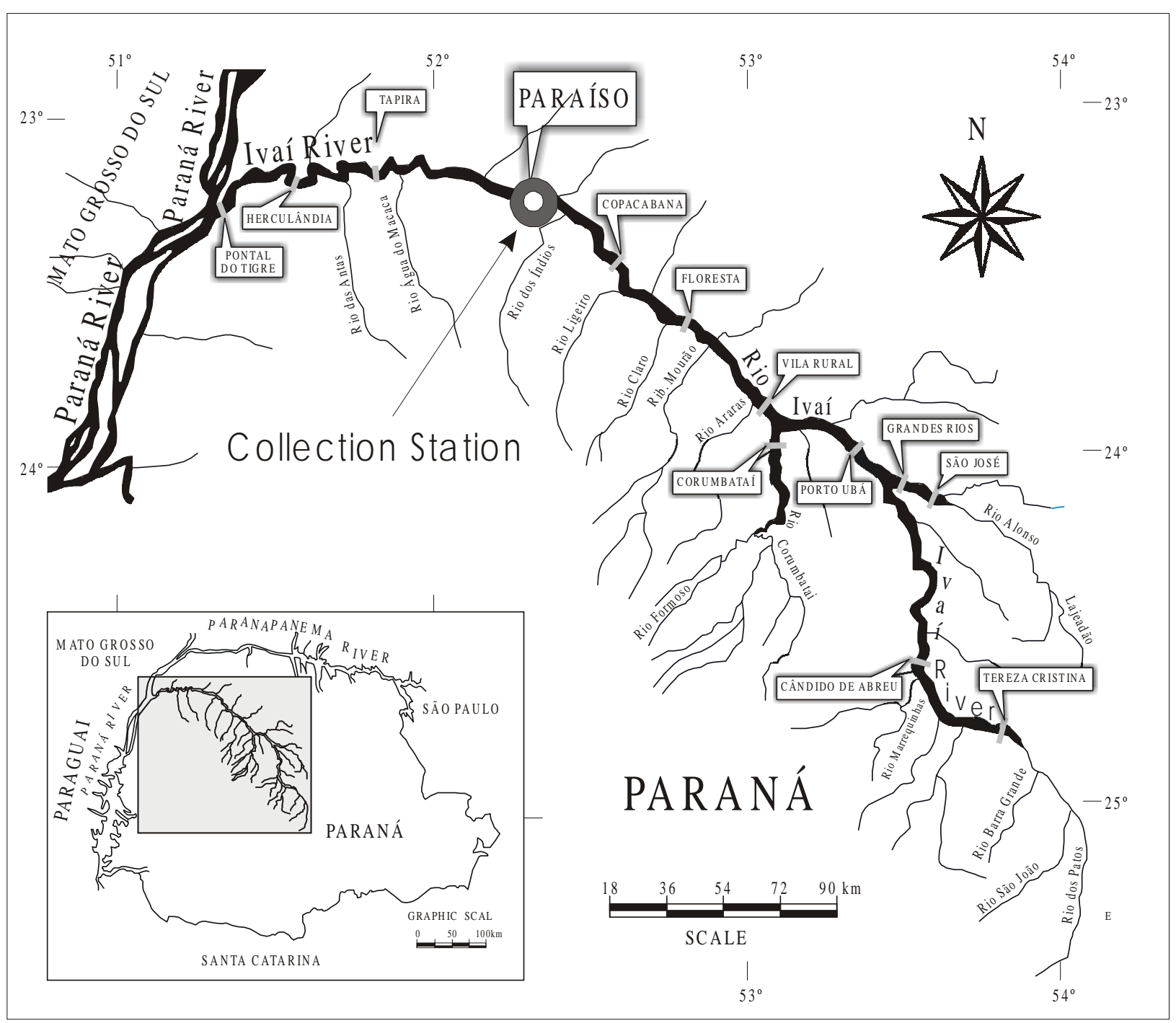

Figure 1 - Localization of the collection station in Paraíso do Norte, state of Paraná (plotted by Jaime Luiz, NUPELIA, UEM).

\section{Statistical analysis}

Data were submitted to statistical analysis of variance and linear correlation (Costa, 1997; Gomes, 1987).

\section{RESULTS AND DISCUSSION}

Table 1 shows the average monthly values, in $\mathrm{mg}$ $\mathrm{L}^{-1}$, of $\mathrm{N} ; \mathrm{K}$, and $\mathrm{P}$ corresponding to values of daily collection samples (5 days per month) analysed in triplicates and the fluviometric levels (FL) corresponding to averages measurement of 
the limnimetric scale in the fluviosedimentometric station of Paraíso do Norte. Table 2 shows monthly average values of COD measurements and corresponding values of $\mathrm{pH}$, temperature and dissolved oxygen in water samples.

Table 1 - Monthly average concentrations (5 days)*, in $\mathrm{mg} \mathrm{L}^{-1}$, of $\mathrm{N}, \mathrm{K}$ and $\mathrm{P}$ of composite samples of water and FL - monthly averages of fluviometric levels** (5 days) at the Fluviosedimentometric Station of Paraíso do Norte, Paraná, Brazil.

\begin{tabular}{|c|c|c|c|c|c|c|c|c|}
\hline \multirow[t]{2}{*}{ month } & \multicolumn{2}{|c|}{$\longleftarrow$} & \multicolumn{2}{|r|}{$\longrightarrow$} & \multicolumn{2}{|c|}{$\longleftarrow$} & \multirow[t]{2}{*}{$\mathbf{K}$} & $\longrightarrow$ \\
\hline & $\mathbf{m}$ & $\pm \mathbf{s}$ & $\mathbf{M}$ & interval & $\mathbf{m}$ & $\pm S$ & & Interval \\
\hline Jan & 1.04 & 0.46 & 1.11 & $0.32-1.59$ & 1.33 & 0.09 & 1.30 & $1.20-1.43$ \\
\hline Feb & 0.99 & 0.27 & 0.95 & $0.72-1.27$ & 1.35 & 0.04 & 1.34 & $1.31-1.40$ \\
\hline Mar & 2.00 & 0.77 & 1.61 & $1.29-3.22$ & 1.29 & 0.06 & 1.28 & $1.23-1.36$ \\
\hline Apr & 1.02 & 0.47 & 1.06 & $0.53-1.69$ & 1.39 & 0.16 & 1.36 & $1.20-1.59$ \\
\hline May & 1.16 & 0.38 & 1.05 & $0.83-1.71$ & 1.13 & 0.23 & 1.02 & $0.97-1.45$ \\
\hline Jun & 2.42 & 0.63 & 2.54 & $1.63-3.17$ & 2.16 & 0.63 & 2.34 & $1.25-2.69$ \\
\hline Jul & 2.38 & 0.36 & 2.38 & $1.90-2.86$ & 2.05 & 0.20 & 2.00 & $1.87-2.38$ \\
\hline Aug & 1.83 & 0.82 & 1.65 & $1.17-2.86$ & 1.23 & 0.08 & 1.25 & $1.13-1.30$ \\
\hline Sep & 1.97 & 0.64 & 1.81 & $1.36-2.95$ & 0.92 & 0.07 & 0.96 & 0.84-0.98 \\
\hline Oct & 1.33 & 0.61 & 1.27 & $0.64-2.22$ & 1.05 & 0.29 & 0.97 & $0.73-1.57$ \\
\hline Nov & 1.87 & 0.64 & 2.20 & $1.11-2.54$ & 1.62 & 0.48 & 1.26 & $1.17-2.22$ \\
\hline Dec & 1.76 & 0.51 & 1.46 & $1.27-2.32$ & 1.09 & 0.19 & 1.05 & $0.81-1.34$ \\
\hline GV & 1.65 & & & $0.32-3.22$ & 1.38 & & & $0.73-2.69$ \\
\hline \multirow{2}{*}{ month } & \multicolumn{2}{|c|}{$\longleftarrow$} & \multicolumn{2}{|l|}{$\mathbf{P}$} & \multicolumn{2}{|c|}{$\longleftarrow$} & \multicolumn{2}{|c|}{$\longrightarrow$} \\
\hline & $\mathbf{m}$ & $\pm \mathbf{s}$ & $\mathbf{M}$ & Interval & $\mathbf{m}$ & $\pm \mathbf{s}$ & $\mathbf{M}$ & interval \\
\hline Jan & 0.020 & 0.012 & 0.020 & $0.006-0.033$ & 1.53 & 0.09 & 1.48 & $1.44-1, .6$ \\
\hline Feb & 0.117 & 0.052 & 0.091 & $0.072-0.202$ & 3.04 & 0.42 & 2.85 & $2.70-3.65$ \\
\hline Mar & 0.051 & 0.038 & 0.039 & $0.006-0.109$ & 1.29 & 0.07 & 1.28 & $1.21-1.38$ \\
\hline Apr & 0.024 & 0.024 & 0.027 & n.d.-0.050 & 1.21 & 0.08 & 1.23 & $1.12-1.32$ \\
\hline May & 0.037 & 0.036 & 0.033 & n.d.-0.083 & 1.26 & 0.34 & 1.53 & 0.94-1.69 \\
\hline Jun & 0.333 & 0.069 & 0.350 & $0.249-0.390$ & 4.74 & 0.66 & 4.68 & $4.00-5.60$ \\
\hline Jul & 0.115 & 0.019 & 0.110 & $0.092-0.137$ & 5.52 & 1.46 & 6.32 & $3.43-6.82$ \\
\hline Aug & 0.082 & 0.010 & 0.078 & $0.076-0.097$ & 1.88 & 0.16 & 1.83 & $1.74-2.10$ \\
\hline Sep & 0.051 & 0.011 & 0.062 & $0.038-0.063$ & 0.97 & 0.02 & 0.97 & $0.95-0.98$ \\
\hline Oct & 0.033 & 0.013 & 0.027 & $0.022-0055$ & 0.91 & 0.02 & 0.92 & $0.88-0.94$ \\
\hline Nov & 0.020 & 0.019 & 0.030 & n.d.-0.030 & 1.12 & 0.15 & 1.05 & $0.99-1.33$ \\
\hline Dec & 0.032 & 0.004 & 0.034 & $0.026-0.036$ & 0.92 & 0.05 & 0.94 & $0.86-0.97$ \\
\hline GV & 0.076 & & & n.d-0.39 & 2.03 & & & $0.86-6.82$ \\
\hline
\end{tabular}

* - Average values for N, K and P correspond to averages of daily values obtained in triplicates; ** Average values correspond to average of values measured in the 5 days of each month; $\mathrm{m}$ - arithmetic average; $\mathrm{s}$ - standard deviation; M - Median; FL Fluviometric Levels; GV - Global Values 
Table 2 - Monthly average values (5 days)* of COD in $\mathrm{mg} \cdot \mathrm{L}^{-1} ; \mathrm{pH}^{* *}$; temperature in ${ }^{\circ} \mathrm{C}^{* *}$; concentration of dissolved oxygen in mg. $\mathrm{L}^{-1 * *}$ of water samples collected at the Fluviosedimentometric Station of Paraíso do Norte, Paraná - Brazil.

\begin{tabular}{|c|c|c|c|c|c|c|c|c|}
\hline \multirow{2}{*}{ month } & \multicolumn{4}{|c|}{$\longleftarrow$ COD $\left({\left.\mathrm{mg} . \mathrm{L}^{-1}\right)} \longrightarrow\right.$} & \multicolumn{2}{|c|}{$\longleftarrow$} & \multicolumn{2}{|c|}{ pH $\longrightarrow \longrightarrow$} \\
\hline & $\mathbf{m}$ & $\mathbf{s}$ & $\mathbf{M}$ & Interval & $\mathbf{m}$ & $\mathbf{S}$ & $\mathbf{M}$ & Interval \\
\hline Jan & $\ldots$ & $\ldots$ & $\ldots$ & $\ldots \ldots$ & 7.02 & 0.51 & 7.21 & $6.21-7.45$ \\
\hline Feb & 23.8 & 6.7 & 23.1 & $15.8-25.3$ & 7.68 & 0.16 & 7.72 & 7.55-7.79 \\
\hline Mar & 6.6 & 1.7 & 6.9 & $4.2-8.4$ & 7.76 & 0.26 & 7.86 & 7.47-7.99 \\
\hline Apr & 2.5 & 3.0 & 1.3 & $0.21-7.5$ & 7.26 & 0.26 & 7.25 & $6.89-7.62$ \\
\hline May & 5.5 & 0.9 & 4.7 & $4.2-6.2$ & 7.28 & 0.20 & 7.33 & $7.00-7.46$ \\
\hline Jun & 24.5 & 10.7 & 34.3 & $10.2-36.7$ & 6.92 & 0.32 & 7.19 & $6.59-7.21$ \\
\hline Jul & 13.1 & 4.6 & 11.6 & 8.4-17.6 & 6.99 & 0.39 & 7.11 & $6.40-7.48$ \\
\hline Aug & 22.8 & 4.5 & 26.5 & $19.0-28.0$ & 6.75 & 0.27 & 8.09 & $7.92-8.50$ \\
\hline Sep & 12.8 & 8.9 & 9.0 & $4.0-27.0$ & 8.15 & 0.27 & 6.75 & $6.72-6.79$ \\
\hline Oct & 11.8 & 10.8 & 8.0 & $3.0-33.0$ & 5.80 & 0.48 & 6.00 & $5.18-6.42$ \\
\hline Nov & 10.0 & 2.0 & 11.0 & $7.0-12.0$ & 7.04 & 0.30 & 6.94 & $6.82-7.62$ \\
\hline Dec & 7.80 & 2.9 & 9.0 & $3.0-11.0$ & 7.14 & 0.43 & 703 & $6.65-7.75$ \\
\hline GV & 12.8 & & & $0.21-36.0$ & 7.15 & & & $5.18-8.50$ \\
\hline \multirow{2}{*}{ month } & \multicolumn{4}{|c|}{$t\left({ }^{0} \mathrm{C}\right)$} & \multicolumn{4}{|c|}{$\longleftarrow \mathrm{O}_{2(\text { dis })}\left(\mathrm{mg}_{\mathrm{L}} \mathrm{L}^{-1}\right)-$} \\
\hline & $\mathbf{m}$ & $\mathbf{S}$ & $\mathbf{M}$ & interval & $\mathbf{m}$ & $\mathbf{S}$ & $\mathbf{M}$ & interval \\
\hline Jan & 26.7 & 1.3 & 26.9 & $25.2-28.4$ & 6.50 & 0.83 & 6.59 & $5.50-7.50$ \\
\hline Feb & 28.2 & 2.0 & 28.4 & $25.5-30.8$ & 5.91 & 0.68 & 5.93 & $4.88-6.76$ \\
\hline Mar & 27.5 & 1.1 & 27.6 & $26.0-29.0$ & 3.18 & 0.92 & 3.32 & $1.89-4.34$ \\
\hline Apr & 24.8 & 0.2 & 24.6 & $22.3-27.7$ & 3.25 & 0.19 & 3.30 & $3.00-3.41$ \\
\hline May & 22.8 & 1.2 & 22.7 & $21.5-24.4$ & 3.11 & 0.22 & 2.98 & $2.80-3.12$ \\
\hline Jun & 21.3 & 1.8 & 20.6 & $20.0-24.0$ & 3.09 & 0.12 & 3.08 & $2.95-3.23$ \\
\hline Jul & 18.4 & 1.9 & 18.0 & $16.0-19.0$ & 6.80 & 0.86 & 6.90 & $6.18-7.80$ \\
\hline Aug & 18.9 & 0.8 & 18.9 & $17.9-19.9$ & 7.10 & 1.12 & 7.05 & $5.90-8.40$ \\
\hline Sep & 23.9 & 3.3 & 27.1 & $19.9-27.6$ & 7.13 & 1.06 & 7.15 & $5.85-8.37$ \\
\hline Oct & 27.6 & 0.5 & 27.5 & $27.0-28.5$ & 6.33 & 0.28 & 6.28 & $5.97-8.25$ \\
\hline Nov & 28.0 & 1.3 & 27.8 & $26.4-295$ & 7.34 & 0.73 & 7.23 & $6.50-8.25$ \\
\hline Dec & 27.2 & 1.3 & 27.4 & $25.0-28.2$ & $\ldots$ & $\ldots$ & $\ldots$ & $\ldots$ \\
\hline GV & 24.6 & & & $16.0-30.8$ & 5.43 & & & $1.89-8.40$ \\
\hline
\end{tabular}

* - Average values correspond to monthly averages (5 days of collection per month) of analysis obtained in triplicates; COD Chemical Oxygen Demand; ** - Values correspond to average of values measured daily (5 days per month); m - arithmetic average; s - standard deviation; M - Median: GV - Global Values.

\section{River Ivaí basin}

During the year, in which samples were taken, periods of drought and heavy rainfall besides normal periods of climate occurred in the basin. Agriculture had its normal stages of soil preparation, plantation and harvest. Soil with or without grass covering was under observation. In the region under analysis, there were cane sugar plantations and burnings as a consequence.
Severe frosts occurred with loss of pastures and cereal plants. In the spring, a prolonged drought delayed the plantation till the end of November, leaving the plowed lime-rich soil without any vegetation waiting for rain for approximately 90 days. Characteristics of such climate were average annual temperatures between $24^{\circ} \mathrm{C}$ and $26^{\circ} \mathrm{C}$, confirmed by overall average annual value of $24.6^{\circ} \mathrm{C}$ (Table 2). 


\section{Macronutrients N, P and K}

The variance analysis for each macronutrient concentration at 5\% level of significance for time variation factor (month of collection), showed significant difference for the three macronutrients. The high values of standard deviation (s) presented in Table 1 and Table 2 mainly for some measured variables, for example, the COD, showed this temporality. An analysis of linear correlation of concentrations of each macronutrient together with fluviometric levels showed the following indexes of linear correlation $\left[\mathrm{r}=\left(\mathrm{R}^{2}\right)^{1 / 2}\right]$ : $\mathrm{N}(\mathrm{r}=0.509)$, Figure 2; $P(r=0.770)$ Figure 3 ; and $K(r=0.859)$ Figure 4. At 5\% level of significance there was a positive correlation between the variables. This showed losses of macronutrients with floodings, indirectly reflecting the influence of erosion and finally the river basin degradation. At 5\% levels of significance, the variables $(\mathrm{COD}, \mathrm{pH}$, temperature and $\mathrm{O}_{2 \text { (dis) }}$ ) of water samples did not affect the concentration of the macronutrients. It was interesting to observe that at $10 \%$ level of significance temperature of samples was correlated negatively with concentrations of macronutrients.

Analysing average values of FL (Table 1) and average values of respective temperatures (Table 2), it was found that during periods of lower temperature there occurred the highest fluviometric levels, thus explaining the negative relation.

COD values were directly proportionate to the level of organic matter and presented positive correlation with the concentration of macronutrients analysed only at $20 \%$ level of significance.

Average annual total concentrations of the three macronutrients in water in the sequence $\mathrm{N}, \mathrm{K}$ and $\mathrm{P}$ were in the proportion 21.6:18.9:1.00. P concentration was 20 times less than that of $\mathrm{N}$ and $\mathrm{K}$. This was due to fixation of phosphorus by iron, aluminum and manganese compounds (Brady, 1989). The chemical equations [01], [02] and [03] show the reactions of $\mathrm{P}$ retention in soil or in particulates dispersed in water and or precipitated.

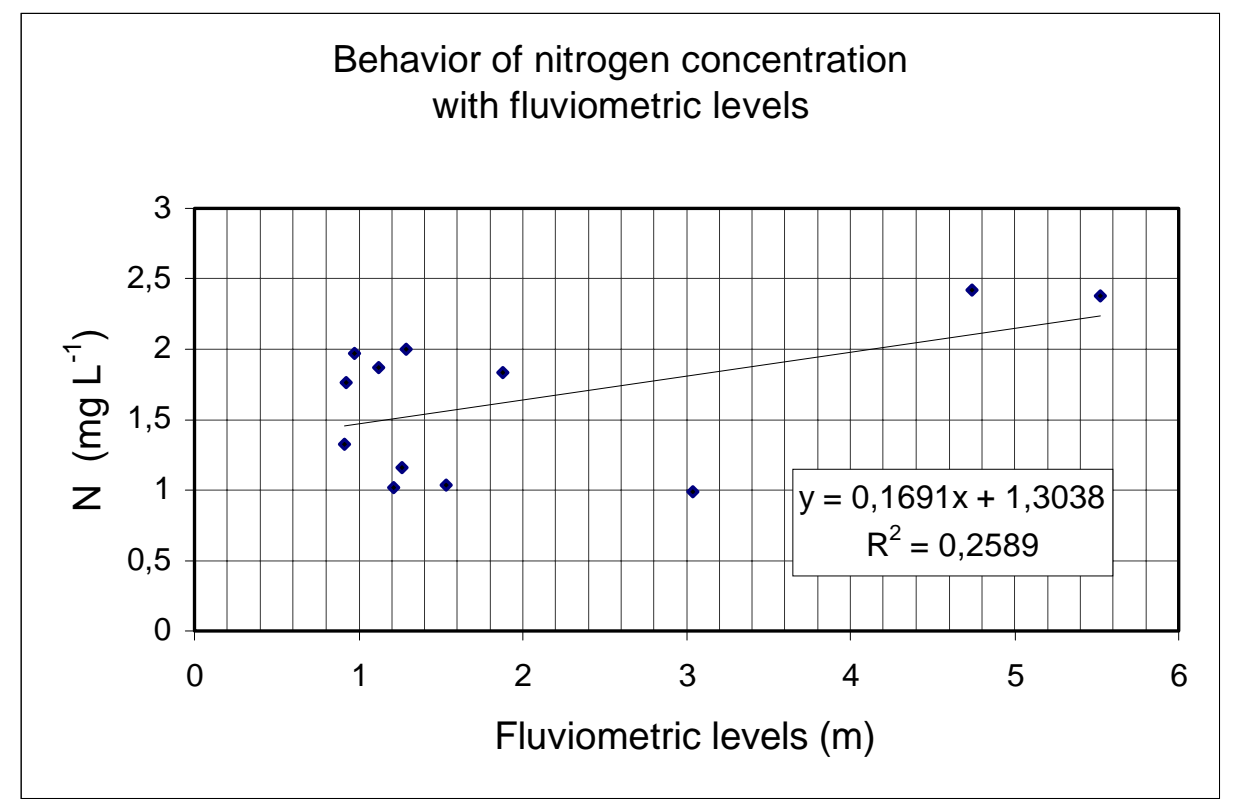

Figure 2 - Correlation of $\mathrm{N}$ concentration with the fluviometric levels. 


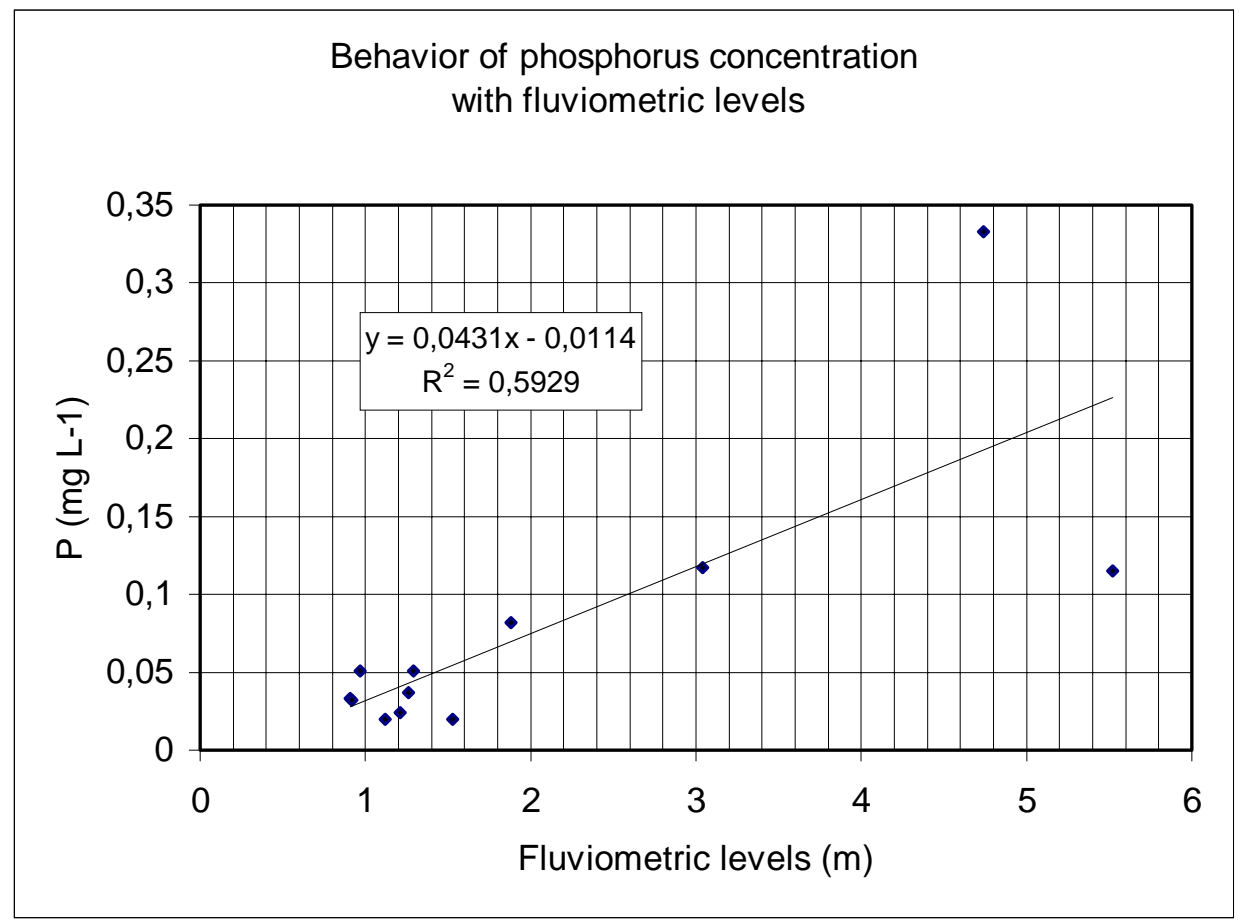

Figure 3 - Correlation of $\mathrm{P}$ concentration with the fluviometric levels.

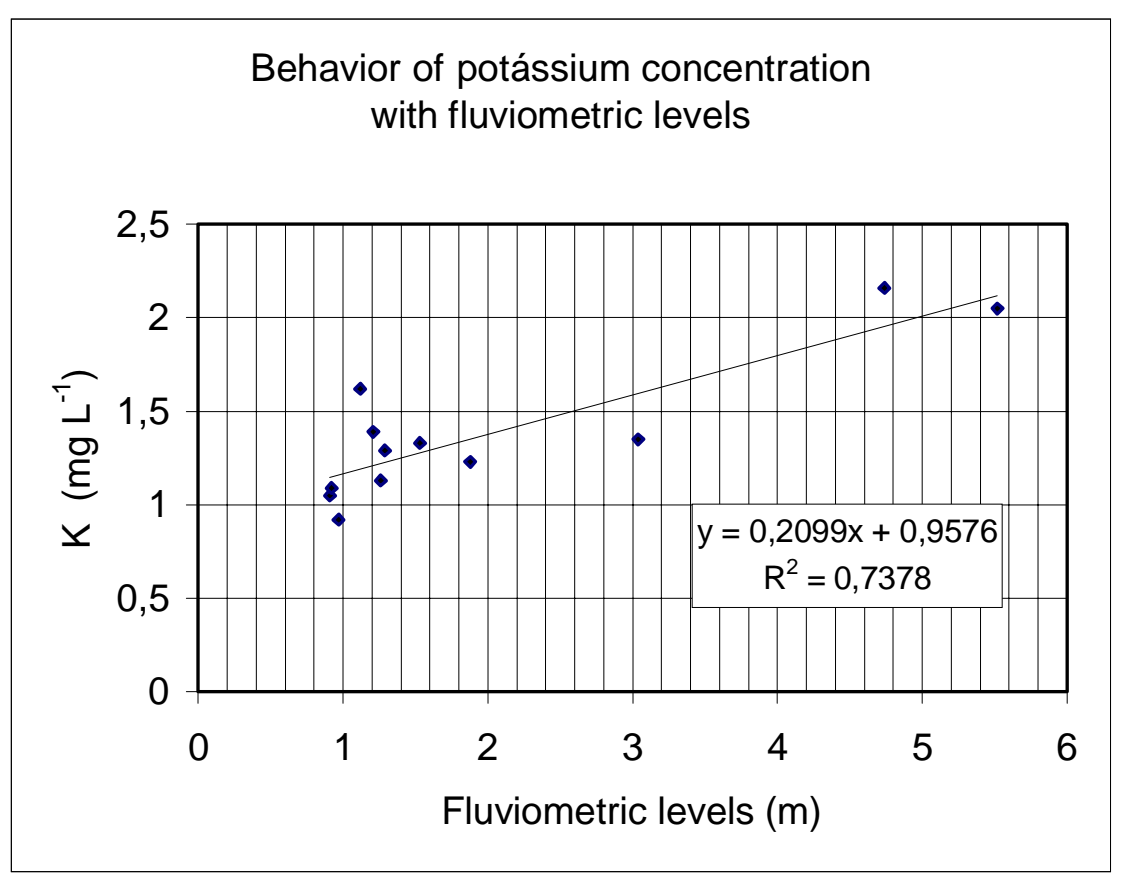

Figure 4 - Correlation of K concentration with the fluviometric levels. 
It becomes less available in soil solution and consequently less eroded, lixiviated and percolated than $\mathrm{N}$ and $\mathrm{K}$ (Malavolta, 1981). Loss by erosion, lixiviation and percolation chiefly depends on quantity of rainfall (Withers and Lord, 2002; Chisci et al. 2001; Zhou and Zhu, 2001).

$$
\begin{aligned}
& \underset{\text { (soluble form) }}{\mathrm{Al}_{(\text {aq) }}^{3+}}+\underset{\text { (soluble form) }}{\mathrm{H}_{2} \mathrm{PO}_{4}^{-}}+2 \mathrm{H}_{2} \mathrm{O}_{(\text {liq) }} \\
& \mathrm{Al}_{2} \mathrm{O}_{3} \cdot 3 \mathrm{H}_{2} \mathrm{O}\left[\mathrm{ou} 2 . \mathrm{Al}(\mathrm{HO})_{3}\right]+2 \mathrm{H}_{2} \mathrm{PO}_{4}^{-} \\
& \text {(oxide-hydroxide insoluble form) (soluble form) } \\
& \underset{\text { (in silicate crystal) }}{[\mathrm{Al}]}+\underset{\text { (soluble form) }}{\mathrm{H}_{2} \mathrm{PO}_{4}^{-}(\mathrm{aq})}+2 \mathrm{H}_{2} \mathrm{O}_{\text {(líq) }}
\end{aligned}
$$

The results were $\mathrm{N}=25,136.0 \mathrm{t} \mathrm{a}^{-1} ; \mathrm{K}=21,020.0$ $\mathrm{t} \mathrm{a}^{-1} ; \quad \mathrm{P}=1,162.2 \mathrm{t} \mathrm{a}^{-1}$ and were compatible to those for the Rivers Baía and Paraná in the region of Porto Rico, Paraná (Lenzi et al., 1992).

The macronutrients losses decrease the soil fertility and consequent productivity. These quantities may be lessened by means of correct soil management achieved by instructions to farm workers, such as contour hedging, contours with permanent grass, direct plantation, crop rotation, etc. The nutrients increase in the water river cause the eutrophication.

\section{CONCLUSIONS}

From the analysis and discussion of data, the following conclusions may be taken:

- Average monthly quantities of $\mathrm{N}, \mathrm{P}, \mathrm{K}$ in the River Ivaí differed from one another significantly at $5 \%$ significance.

- The same averages showed positive linear correlation (r) with their respective fluviometric levels at 5\% level, showing higher losses in flooding period.

- At 5\% level of significance, influence of COD, $\mathrm{pH}$, temperature and dissolved oxygen was not observed in the water samples on the respective quantities of $\mathrm{N}, \mathrm{P}$, and $\mathrm{K}$ carried away by the Ivaí waters.

- Proportion of N, P, and K quantities carried away by the waters was 21.6:18.9:1.00, respectively.

- In terms of average annual values, quantities of $\mathrm{N}$, $\mathrm{P}, \mathrm{K}$ carried away from the basin were $\mathrm{N}=$ $25,136.0 \mathrm{ta}^{-1} ; \mathrm{K}=21,010.0 \mathrm{ta}^{-1} ; \mathrm{P}=1,162.2 \mathrm{ta}^{-1}$.
Amounts of N, P and K carried off the River Ivaí basin could be estimated when total annual average $\left(\mathrm{N}=1.65 ; \mathrm{P}=0.076 ; \mathrm{K}=1.38, \mathrm{mg} \mathrm{L}^{-1}\right.$ respectively) and the average discharge of the River Ivaí for the period 1954-1981 (483 $\left.\mathrm{m}^{3} \cdot \mathrm{s}^{-1}\right)$ were taken into consideration.

$$
\begin{aligned}
& \leftrightarrows \quad 2 \mathrm{H}^{+}{ }_{(\mathrm{aq})}+\underset{\text { (insoluble form) }}{\mathrm{Al}(\mathrm{HO})_{2} \mathrm{H}_{2} \mathrm{PO}_{4(\mathrm{ppt})}} \\
& \leftrightarrows 2 \mathrm{Al}(\mathrm{HO})_{2} \mathrm{H}_{2} \mathrm{PO}_{4}+2 \mathrm{HO} \\
& \text { (insoluble form) } \\
& \leftrightarrows 2 \mathrm{H}^{+}{ }_{(\text {aq) }}+\underset{\text { (insoluble form) }}{\mathrm{Al}(\mathrm{HO})_{2} \mathrm{H}_{2} \mathrm{PO}_{4}}
\end{aligned}
$$

\section{ACKNOWLEDGEMENTS}

The research team would like to thank the Chemistry Department, the Environmental Multidisciplinary Studies Group (GEMA), the Research Nucleus in Limnology, Ichthyology and Aquiculture (NUPELIA) of the State University of Maringá, the Chemistry Department of the Federal University of Paraná and to CAPES.

\section{RESUMO}

Neste estudo foram analisadas algumas variáveis ambientais que influenciam a perda de macronutrientes ( $\mathrm{N}, \mathrm{P}$ e $\mathrm{K}$ ) na bacia hidrográfica do rio Ivaí, afluente do rio Paraná. As amostras compostas de água foram coletadas mensalmente, em 5 dias consecutivos, durante um ano. No ato da coleta foram medidos, o $\mathrm{pH}$, a temperatura, o $\mathrm{O}_{2 \text { (dissolvido) }}$ e os níveis fluviométricos. $\mathrm{O} \mathrm{N}$ total foi determinado pelo método de Kjeldahl. Após a digestão das amostras com redução de volume foram determinados, o $\mathrm{P}$ total, pelo método espectrofotométrico do UV-Vis com ácido ascórbico e $\quad \mathrm{o} \quad \mathrm{K}$ total pela técnica da espectrometria da absorção atômica. O DQO foi determinado pelo método da oxidação da matéria orgânica pelo $\mathrm{K}_{2} \mathrm{Cr}_{2} \mathrm{O}_{7}$, em excesso, em ácido sulfúrico concentrado. Em termos de intervalos das médias mensais, média global, os resultados experimentais foram os seguintes, em $\mathrm{mg} \mathrm{L}^{-1}: \mathrm{N}$ (0,32-3,22 e 1,65); K (0,73-2,69 e 1,38); P (não detectado-0,39 e 0,076); COD (0,21-36,0 e 12,8); $\mathrm{O}_{2 \text { (diss) }}(1,89-8,40$ e 5,43$)$; e, temperatura $\left({ }^{0} \mathrm{C}\right)$ $(16,0-30,8$ e 24,6$)$; pH $(5,18-8,50$ e 7,15$)$. A 
análise estatística dos dados mostrou que a quantidade de cada macronutriente levada pelas águas do rio Ivaí é diretamente correlacionada aos níveis fluviométricos do rio, em nível de $5 \%$ de confiança. As quantidades perdidas em $\mathrm{t} \mathrm{a}^{-1}$ foram: $\mathrm{N}=25.136,0 ; \mathrm{K}=21,010,0$ e $\mathrm{P}=1,161,2$, respectivamente.

\section{REFERENCES}

Ahn, T. B.; Cho, S. D. and Yang, S. C. (2002), Stabilization of soil slope using geosynthetic mulching mat. Geotextiles and Geomembranes, 20, 135-146.

Alegre, J. C. and Rao, M. R. (1966), Soil and water conservation by contour hedging in the humid tropics of Peru. Agric. Ecosyst. and Environ., 57, 17-25.

Auzet, A.; Poesen, J. and Valentin, C. (2001), Soil patterns as a key controlling factor of soil erosion by water. Catena, 46, 85-87.

Bartram, J. and Balance, R. (1996), Water Quality Monitoring - A practical guide to the design and implementation of freshwater quality studies and monitoring programmes London : E and FN Spon.

Bittencourt, A. V. L. (1982), Transporte de sólidos na bacia hidrográfica do rio Ivaí (Solids transport in the hydrographic basin of the Ivaí river). Bol. Parana. Geociênc., 35, 1-54.

Blair, J. M. and McScherry, L. (1996), Sustainable agriculture in the Southwest United States and its relationship to landscape planning. J. Soil Water Conserv., 51 : (4), 280-284.

Brady, N. C. (1979), Natureza e propriedades dos solos (The nature and properties of soils). Rio de Janeiro : Livraria Freitas Bastos.

Braile, P. M. and Cavalcanti, J. B. W. C. (1993), Manual de tratamento de águas residuárias $e$ industriais (Manual of wastewaters and industrials waters treatment). São Paulo : CETESB.

Busscher, W. J.; Reeves, D. W.; Kochhann, R. A.; Bauer, P. J.; Mullins, G. L.; Clapham, W. M.; Kemper, W. D. and Galerani, P. R. (1996), Conservation farming in Southern Brazil: using cover crops to decrease erosion and increase infiltration. $J$. Soil Water Conserv., 51 : (3), 188-192.

Cerdan, O.; Le Bissonnais, Y.; Couturier, A.; Bourennane, H. and Souchère, V. (2002), Rill erosion on cultivated hillslopes during two extreme rainfall events in Normandy, France. Soil Tillage Res., 1716, 01-10.

CETESB (1978), Normalização Técnica Saneamento Ambiental, NT - 07 - Análises físico-químicas de águas (Technical normatization of environmental sanitation, NT - 07 - water physico-chemical analyses). a)L.5.139/78; b)L5.128/78; c)L5.012/78. São Paulo : CETESB.
Chisci, G. C.; Bazzoffi, P.; Pagliai, M.; Papini, S. and Vignozzi, N. (2001), Association of sulla and atriplex shrub for physical improvement of clay soils and environmental protection in central Italy. Agric., Ecosys. Environ., 84, 45-53.

Costa Neto, P. L. D. (1997), Estatística (Statistics). São Paulo : Edgard Blucher.

Dalton, P. A.; Smith, R. J. and Truong, P. N. V. (1996), Vetiver grass hedges for erosion control on a cropped flood plain: hedge hydraulics. Agric. Water Manage, 31, 91-104.

Dewald, C. L.; Henry, J.; Bruckerhoff, S.; Ritchie, J.; Dabney, S.; Shepherd, D.; Douglas, J. and Wolf, D. (1996), Guidelines for establishing warm season grass hedges for erosion control. J. Soil Water Conserv., 51 : (1), 16-20.

Drechsel, P.; Gyele, L.; Kunze, D. and Cofie, O. (2001), Population density, soil nutrient depletion, and economic growth in sub-Saharan Africa. Ecol. Econ., 38, 251-258.

Esteves, F. A. (1988), Fundamentos de Limnologia (Fundamentals of limnology). Rio de Janeiro : Interciência.

Gomes, F. P. (1987), Curso de Estatística Experimental (Course of experimental statistics). Rio de Janeiro : Nobel.

Hoag, D. L. and Skold, M. D. (1996), The Relationship between conservation and sustainability. J. Soil Water Conserv., 51 : (4), 292-295.

Horwitz. W. (ed.) (1980), Official Methods of Analysis of the Association of Official Analytical Chemists. 13. ed. Washington : AOAC.

Ingram, J. and Lee, Valentin, C. (1996), The GCTE soil erosion network: A multi-participatory research program. J. Soil Water Conserv., 51 : (5), 377-388.

Jaworski, A. N.; Groffman, P. M.; Keller, A. A., J. C. and Prager, J. C. (1992), A Watershed nitrogen and phosphorus balance: The upper Patomac River Basin. Estuaries, 15 : (1), 83-95.

Keith. L. H. (ed.) (1996), Principles of Environmental Sampling. 2. ed. Washington : American Chemical Society.

Kloke, N. L.; Schneekloth, J. P. and Watts, D. G. (1996), Potencial for reducing leaching by water and crop rotations. J. Soil Water Conserv., 51 : (1), 84-90.

Lenzi, E.; Luchese, E. B.; Rauber, T.; Oliveira, M. A. and Palacio, S. M. (1992), Níveis de concentração dos macronutrientes $\mathrm{N}, \mathrm{P}$ e $\mathrm{K}$ que aportam nos rios Paraná e Baía, na região de Porto Rico - PR (Concentrations levels of the macronutrients N, P and $\mathrm{K}$ that arrive in the Paraná and Baía rivers, region of Porto Rico - PR). Acta Limnol. Brasil., 4, 239-245.

Lee, L. K. (1996), Sustainability and land-use dynamics. J. Soil Water Conserv., 51 : (4), 295.

Malavolta, E. (1981), Manual de Química Agrícola (Manual of agricultural chemistry). São Paulo : Agronômica Ceres. 
Malik, R. H.; Green, T. H.; Brown, G. F.; Mays, D. (2000), Use of cover crops in short rotation hardwood plantations to control erosion. Biomass and Bioenergy, 18, 479-487.

Manahan, S. E. (1994), Environmental Chemistry. 6. ed. Boca Raton (Florida) : Lewis Publishers.

Mart, L. (1979), Prevention of contamination and other accuracy risk in voltammetric trace metal analysis of natural waters. Part I. Preparatory steps, filtration and storage of waters samples. Fresenius Z. Anal. Chem., 296, 350-357.

Midimore, D. J.; Jansen, H. G. P. and Dumsday, R. G. (1996), Soil Erosion and Environmental Impact of Vegetable Production in the Cameron Highlands, Malaysia. Agric. Ecosyst. and Environ., 60, 29-46.

Moody. J. R. and Lindstrom. R. M. (1977), Selection and cleaning of plastic containers for storage of trace element samples. Anal. Chem., 49 : (14), 2264-2267.

Perret, S.; Michellon, R.; Boyer, J. and Tassin, J (1996), Soil rehabilitation and erosion control through agroecological pratices on reunion Island (French Overseas Territory, Indian Ocean). Agric. Ecosyst. and Environ., 59, 149-157.

Poesen, J. W.; Boardman, J.; Wilcox, B. and Valentin, C. (1996), Water erosion monitoring and experimentation for Global Change Studies. J. Soil Water Conserv., 51 : (5), 386-390.

Rose, S. C.; Harris, G. L.; Armstrong, A. C.; Willians, J. R.; Howse, K. R. and Tranter, N. (1991), The leaching of agrochemical under different agricultural land uses and its effect on Water Quality. IAHS Publication, 203, 249-257.

Rosensteel, B. A. and Strom, P. F. (1991), River phosphorus dynamics and reservoir eutrophication potencial. Water Resour. Bull., 27 : (6), 957-965.

Rossi, N.; Ciavatta, C. and Antisari, L. V. (1991), Seasonal pattern of nitrate losses from cultivated soil with subsurface drainage. Water, Air and Soil Pollut., 60, 1-10.

Sequi, P.; Ciavatta, C. and Antisari, L. V. (1991), Phosphate fertilizers loading to river and seawater. Agrochimica, 35 : (1-3), 200-211.

Souza, H. B. and Derísio, J. C. (1977), Guia Técnico de Coleta de Amostras de Água (Technical guide of water samples collecting). São Paulo : Companhia de Tecnologia de Saneamento Ambiental.

Thompson, J. and Pretty, J. N. (1996), Sustainability indicators and soil conservation. J. Soil Water Conserv., 51 : (4), 265-273.
Usón, A. and Ramos, M. C. (2001), An improved rainfall erosivity index obtained from experimental interrill soil losses in soils with a Mediterranean climate. Catena, 43, 293-305.

Van Muysen, W. and Govers, G. (2002), Soil displacement and tillage erosion during secondary tillage operations: the case of rotary harrow and seeding equipment. Soil Tillage Res., 65, 185-191.

Wagner, R. (1976), Sampling and sample preparation water. Fresenius Z. Anal. Chem., 282, 315-321.

Welz. B. and Sperling. M. (1999), Atomic Absorption Spectrometry. 3. ed. rev. VCH Verlagsgesellschaft $\mathrm{mbH}$, Weinheim (Germany).

Williams, J.; Nearing, M.; Nicks, A.; Skidmore, E.; Valentin, C.; King, K. and Savabi, R. (1996), Using soil erosion models for Global Change Studies. J. Soil Water Conserv., 51 : (5), 381-385.

Withers, P. J. A.; Lord, E. I. (2002), Agricultural nutrient inputs to rivers and groundwaters in the UK: policy, environmental management and research needs. Sci. Total Environ., 23, 09-24.

WMO - World Meteorological Organization (1988), Manual on Water-Quality Monitoring. Operational Hydrology Report n. 27. Geneva : Secretariat of the Meteorological Organization.

Wyland, L. J.; Jackson, L. E.; Chaney, W. E.; Klonski, K.; Koike, S. T. and Kimple, A. (1996), Winter cover crops in a vegetable cropping system: impacts on nitrate leaching, soil, water, crop yield, pests and management costs. Agric. Ecosyst. and Environ., 59, 1-17.

Zhou, J. and Zhu, J. (2001), Runoff loss ways of nutrients in non-irrigated farmland in Hefei outskirts. The J. App. Ecol., 12 : (3), 391-394.
Received: June 21, 2002; Revised: October 16, 2003; Accepted: May 10, 2004. 